\title{
Factors Associated With Adherence To Iron Supplementation Among Pregnant Women
}

\author{
Septi Indah Permata Sari ${ }^{1}$, Wiwik Kusumawati ${ }^{2}$, Anjarwati ${ }^{3}$ \\ ${ }^{1}$ Univrsitas Muhammadiyah Yogyakarta, Yogyakarta, Indonesia (55292) \\ 2,3 Universitas Aisyiyah Yogyakarta, Yogyakarta, Indonesia (55292) \\ Email: septiindahps07@gmail.com
}

\begin{abstract}
Abstrak
Kontribusi anemia terhadap kematian ibu hamil di Indonsia diperkirakan mencapai 10\% hingga $12 \%$. Upaya pemerintah untuk menanggulangi anemia terfokus pada program pemberian suplementasi tablet zat besi sejak 1974, namun prevalensi anemia pada ibu hamil tetap tinggi. Penyebabnya yaitu ketidakpatuhan dalam mengonsumsi tablet. Untuk mengetahui faktor-faktor yang berhubungan dengan kepatuhan ibu hamil mengonsumsi tablet zat besi di Puskesmas Tegalrejo Yogyakarta. Penelitian ini merupakan penelitian mixed methode, dengan menggunakan strategi sequential explanatori. Teknik pengambilan sampel kuantitatif menggunakan teknik consecutive sampling didapatkan 81 ibu hamil dan intensity sampling untuk penelitian kualitatif didapatkan 13 orang informan. Berdasarkan hasil analisis, faktor yang berhubungan dengan kepatuhan ibu hamil mengonsumsi tablet zat besi diantaranya pengetahuan $(p=0,000)$, dukungan suami $(p=0,000)$ dan dukungan bidan $(p=0,000)$. Nilai Exp(B) paling besar yaitu pada variabel dukungan suami sebesar 15.297. Artinya ibu hamil dengan dukungan suami memiliki peluang 15.297 kali lebih besar untuk patuh mengonsumsi tabet zat besi. Berdarkan wawancara dengan informan didapatkan bahwa suami dan bidan mendukung dalam mengonsumsi tablet zat besi. Faktor-faktor yang berhubungan dengan kepatuhan ibu hamil mengonsumsi tablet zat besi di Puskesmas Tegalrejo Yogyakarta yaitu pengetahuan, dukungan suami dan dukungan bidan.
\end{abstract}

Kata Kunci : Faktor-faktor, Kepatuhan, Tablet Zat Besi

\begin{abstract}
In Indonesia, the contribution of anemia towards maternal mortality is estimated to reach $10 \%$ up to $20 \%$. The effort of the government to overcome anemia focuses on iron supplementation program since 1974, but the prevalence of anemia in pregnant mother still relatively high. The factor is discompliance in taking medicine. This study aimed to analyse the factors that related to the compliance of pregnant mother in taking the iron tablet at the Tegalrejo Community Health Centers, Yogyakarta. This research used mixed methods by using sequential explanatory strategy. The quantitative sample is taking used consecutive sampling technique, which presented 81 pregnant mothers and intensity sampling for qualitative research presented 13 informants. Based on the result of the analysis, the factors which related to the Compliance of pregnant mother in taking iron tablet were knowledge $(p=0,000)$, husband support $(p=0,000)$ and midwife support $(p=0,000)$. The most significant $\operatorname{Exp}(B)$ score was the variable of husband support, which was 15.297. It concluded that pregnant mothers who got support from their husbands would be 15.297 times more significant to obey in taking the iron tablet. Based on the interview of the informants showed that both husband and midwife support in taking an iron tablet. The factors related to the Compliance of pregnant mother in taking the iron tablet at clinic government Tegalrejo, Yogyakarta was knowledge, husband and midwife supports.
\end{abstract}

Keyword: Factors, Compliance, Iron Tablet, Pregnant Mother 
Article info:

Article submitted on March 03, 2019

Articles revised on April 11, 2019

Articles received on May 10, 2019

DOI: http://dx.doi.org/10.21927/jnki.2019.7(2).111-117

\section{INTRODUCTION}

Anemia is a condition where hemoglobin concentration is under the standard limit, which disrupts blood capacity to transport oxygen throughout the body (1). World Health Organization (WHO) predicts that the total number of people experience anemia worldwide becomes very high, and the global anemia prevalence is predicted reaching $30,02 \%$ to pregnant women increased to $41,08 \%$ (2). The prevalence of pregnant mothers who suffer anemia in Indonesia is predicted, reaching $50 \%$ to $63,00 \%$ in 2015 (3).

Indonesia has committed iron supplementation program, but the anemia prevalence in pregnant mother still relatively high year by year (4). Gibney et al., (2009) states that inadequate distribution number and the compliance of pregnant mother in taking the iron tablet is the factor which determines the accomplishment of overcoming program. High-level knowledge of pregnant mother upon anemia and iron tablet can form positive behaviour toward compliance (6). Support by a health worker, especially midwife is vital to make pregnant mother aware of a healthy pregnancy, which may be changed into pathology if she does not keep her health (7).

Bored, nausea, vomit, constipation, which are mentioned by mothers in Bicol, Philippine and Senegal is possible to happen to some pregnant mothers who eat iron (8). This one of a factor which makes mothers become discompliance to take medicine, here the support of husbands is essential to make their wife's disposed to take medicine regularly (6). Support from various parties is significant, considering that this tablet should be eaten every day in the long-term (7).
The graph of the occurrence of anemia in Yogyakarta in recent years shows that Yogyakarta occupies the position with the highest occurrence of anemia for three consecutive years, which are $24,13 \%$ in $2013,32,39 \%$ in 2015 (3). The mother's Compliance to take iron supplement goes down is one of the reasons why anemia prevalence still relatively high . Based on the interview survey which committed by the department of health in Yogyakarta, Yogyakarta is at the lowest position with compliance presentation reaching $50 \%$ where the indicator of the compliance which used is taking medicine 90 tablets minimum every day during pregnancy. There are $29,05 \%$ of pregnant mothers who take $<90$ tablet medicine during pregnancy and $21,07 \%$ of pregnant mothers do not take iron supplementations because of forgetting.

The clinic government in Tegalrejo was selected to be the location for research by the consideration that anemia pregnant mother still relatively high where the total of pregnant mothers was many and $\mathrm{Fe} 3$ percentages were still low. An early study which committed to 10 pregnant mothers at the clinic government in Tegalrejo on 25 April 2017 presented that the mothers often forgot to take medicine, bored, dislike the smell of the tablet and make them queasy. The purpose of this study was to analyze the factors associated with compliance of pregnant women taking iron tablets at the Tegalrejo Public Health Center in Yogyakarta

\section{MATERIALS AND METHODS}

This research is non-experimental research with a mixed-methods approach, namely research by combining quantitative and qualitative research. 
The strategy used is sequential explanatory, where quantitative data is collected first, after which qualitative data collected. In this sequential explanatory strategy, weighting or priority is given more to quantitative data. The population in this study was 417 pregnant women. For quantitative research, using survey methods, the sampling technique used in this study was consecutive sampling. The number of samples for quantitative research used as many as 81 third trimester pregnant women. Then, quantitative data analysis uses univariate, bivariate analysis with Chi-Square, and multivariate using logistic regression. As for qualitative research using phenomenological design. Data collection techniques carried out by in-depth interviews. The sampling technique was by purposive sampling with an intensity sampling strategy. The number of samples used in qualitative research amounted to 8 pregnant women with supporting informants 2 midwives and 3 husbands. Triangulation used is a triangulation of data sources through interviews and observations.

\section{RESULTS AND DISCUSSION}

Based on table 1, could be informed that the majority of respondents obey to consumption iron tablet was $55.6 \%$ (45 respondents) and had an excellent knowledge was 46.9\% (38 respondents). Husband supported the majority was $63.0 \%$ (51 respondents) and supported by midwives was $79 \%$ (64 respondents). Most respondents experience mild side effect was $55.6 \%$ (45 respondents).

The result of analysis used chi-square statistic presented knowledge with $p$ value $=0.000$,

Table 1. The distribution of respondents frequency based on compliance, knowledge, husband support, midwife support, and side effect of iron tablets.

\begin{tabular}{lcc}
\hline $\begin{array}{l}\text { Distribution Frequency-based: } \\
\text { Compliance with taking }\end{array}$ & $\mathbf{n}(\mathbf{n}=\mathbf{8 1})$ & $\mathbf{1 0 0 \%}$ \\
$\begin{array}{l}\text { medicine iron tablet } \\
\quad \text { Obey }\end{array}$ & & \\
$\quad$ Disobey & 45 & 55.6 \\
Knowledge & 36 & 44.4 \\
$\quad$ Excellent & 38 & 46.9 \\
$\quad$ Sufficient & 36 & 44.4 \\
$\quad$ Low & 7 & 8.6 \\
Husband support & & \\
$\quad$ Supported & 51 & 63.0 \\
$\quad$ Not supported & 30 & 37.0 \\
Midwife support & & \\
$\quad$ Supported & 64 & 79.0 \\
$\quad$ Not supported & 17 & 21.0 \\
The side effect of iron tablet & & \\
$\quad$ No side effect & 27 & 33.3 \\
$\quad$ Mild & 45 & 55.6 \\
$\quad$ Normal & 9 & 11.1 \\
$\quad$ Hard & 0 & 0 \\
\hline
\end{tabular}

Source: Primary and Secondary, made in 2017

Table 2. The relationship among knowledge, husband support, midwife support and side effect with compliance to consumption iron tablet

\begin{tabular}{|c|c|c|c|c|c|c|c|c|}
\hline \multirow{3}{*}{ Variable } & \multirow{3}{*}{ Parameter } & \multicolumn{4}{|c|}{$\begin{array}{l}\text { Compliance with consumption } \\
\text { iron tablet }\end{array}$} & \multirow{2}{*}{\multicolumn{2}{|c|}{ Total }} & \multirow{3}{*}{$p / p$-Value } \\
\hline & & \multicolumn{2}{|c|}{ Obey } & \multicolumn{2}{|c|}{ Disobey } & & & \\
\hline & & $\mathrm{N}$ & $\%$ & $\mathrm{~N}$ & $\%$ & $\mathrm{~N}$ & $\%$ & \\
\hline \multirow[t]{3}{*}{ Knowledge } & Excellent & 30 & 37.0 & 8 & 9.9 & 38 & 46.9 & \multirow{3}{*}{0.000} \\
\hline & Sufficient & 12 & 14.8 & 24 & 29.6 & 36 & 44.4 & \\
\hline & Low & 3 & 3.7 & 4 & 4.9 & 7 & 8.7 & \\
\hline \multirow[t]{2}{*}{ Family support } & Support & 38 & 46.9 & 13 & 16.0 & 51 & 63.0 & \multirow[b]{2}{*}{0.000} \\
\hline & Not support & 7 & 8.6 & 23 & 28.4 & 30 & 37.0 & \\
\hline \multirow[t]{2}{*}{ Midwife support } & Support & 43 & 53.1 & 21 & 25.9 & 64 & 79.0 & \multirow[b]{2}{*}{0.000} \\
\hline & Not support & 2 & 2.5 & 15 & 18.5 & 17 & 21.0 & \\
\hline \multirow[t]{4}{*}{ Ironside effect } & Not experience & 18 & 22.2 & 9 & 11.1 & 27 & 33.3 & \multirow{4}{*}{0.340} \\
\hline & Mild & 23 & 28.4 & 22 & 27.2 & 45 & 55.6 & \\
\hline & Sufficient & 4 & 4.9 & 5 & 6.2 & 9 & 11.1 & \\
\hline & Hard & - & - & - & - & - & - & \\
\hline Total & & 45 & 56.6 & 36 & 44.4 & 81 & 100 & \\
\hline
\end{tabular}

Source: primary and secondary, made in 2017 
husband support with $p$-value $=0.000$, midwife support with $p$-value $=0.000$ showed two significant relationships among knowledge, husband support and midwife support with compliance to consumption iron tablet at clinic government, Tegalrejo, Yogyakarta. Then, the side effect with value $p$-value $=0.340$ showed none of the significant relationships between side effect and mother's compliance to consumption iron tablet.

Tabel 3. The relationship among knowledge, husband support, midwife support and side effect with compliance to consumption iron tablet

\begin{tabular}{lcc}
\hline \multicolumn{1}{c}{ Variable } & Model 1 & Model 2 \\
& OR & OR \\
& $95 \% \mathrm{Cl}$ & $95 \% \mathrm{Cl}$ \\
\hline Midwife wupport & 15.297 & 11.597 \\
& $(2.316-101.027)$ & $(2.004-67.109)$ \\
Husband support & 5.996 & 6.444 \\
& $(1.753-20.507)$ & $(1.912-21.719)$ \\
Knowledge & 0.283 & 0.255 \\
& $(0.108-0.744)$ & $(0.099-0.655)$ \\
Education & 1.553 & \\
& $(0.676-3.567)$ & \\
\hline $\mathrm{R}^{2}$ & 0.532 & 0.521 \\
-2 Log likelihood & 70.249 & 71.344 \\
Overall percentage & 75.3 & 77.8 \\
\hline
\end{tabular}

Source: primary and secondary, made in 2017

Based on what mentioned, model number 1 was selected to explain the relationship between the compliance of pregnant mothers to consumption iron tablet by considering high-value $\mathrm{R}^{2}$ and the smallest parsimony value (-2 log-likelihood). Multivariate analysis results have proven a hypothesis that midwife relationship with pregnant mother's compliance with consumption iron $(p=0.000)$ where the mothers who got support from their husbands would 15.297 times obey.

\section{Discussion}

Knowledge is one of a factor which affects the compliance in consumption iron tablet, especially knowledge that connects to advantage and disadvantage if the pregnant mothers consume the iron tablet. Based on chi-square statistic test with the level of trust $95 \%(\alpha=0,05 \%)$ presented that there was the significant relationship between knowledge and the compliance of the pregnant mothers in taking an iron medicine with $p$-value 0,000 . It was supported by the results of interviews conducted and reviewed using qualitative analysis where pregnant women say that iron was good for pregnancy even though they would feel bored, but for the baby and his health, the mothers were still consuming it regularly. Based on the results of interviews in the field, it found that there were still pregnant women who were not compliant to consume iron tablets for various reasons.

Non-compliance can have an impact on the incidence of mild, moderate, and even severe anemia. Pregnant mothers with excellent educated would behave positively in preventing or healing anemia (4). In his research in Amhara, Africa mentions that the decrease of anemia number at pregnant mothers cannot be decreased finely if those mothers do not want to fix themselves (9). Good behaviour which occurred from inside is more influential than what comes from outside.

The assignment of a midwife in giving optimal health service is expected for pregnant mothers to make their knowledge developed. It is fit in the interview committed by midwives, where midwives have shared explanation about anemia iron tablet at early pregnancy then repeated when mothers experience the explanation at trimester II.

The support of midwife was one of a factor which influenced mothers to obey consumption of the iron tablet. Based on the chi-square statistic with the level of trust $95 \%(\alpha=0,05 \%)$ stated that there was a significant relationship between midwife support and mothers' Compliance in taking the iron tablet with $p$-value 0,000. Based on the informants where midwives shared counselling about the iron tablet, manner, time, 
the frequency of consumption, and how to overcome occurred side effect, and the midwife also provided iron tablet.

It was observed in the field that midwives had given explanations about iron tablets to every pregnant woman, but there were still many pregnant women who did not follow the midwife's advice. It was supported by the results of qualitative analysis where midwives say that they had shared KIE about anemia, iron tablet, since trimester I of pregnancy and to make all pregnant mothers received 90 tablets during pregnancy. In line with research made by Wiradnyani and friends (2013) wherein every visit, the mothers will receive information and medicines needed during pregnancy. In solving pregnancy problems, midwives must be friendly, correct, caring for each visiting mother. In solving pregnancy issue, the midwife must behave in a friendly way, right, care for every mother who visits (11). Midwives as female friends must know about the needs during pregnancy, physical and mental support is needed when women in pregnancy, childbirth and even after giving birth (15). Midwives say that the best support should be from the husband. The support of husband has significant contribution in supporting the pregnant mother to a consume iron tablet, their care to remind is needed to remember why medicine needed to be consumed every day (12).

The contribution of the family, especially husband, is significant as a strengthener factor in increasing the Compliance to consumption iron (10). Based on chi-square statistic test with the level of trust $95 \%(\alpha=0,05 \%)$ showed that there was a significant relationship between husband support and the Compliance of pregnant mother to consume iron tablet with $p$-value 0,000 . Husband support is a vital factor that determines iron supplementation (10). It was supported by the results of qualitative analysis which pregnant women say thatthat the husbands showed their support by reminding the mother to consume the medicine and to search for information needed during pregnancy.

If the husband cares by giving attention and monitoring the consumption of iron every day will increase Compliance (13). It wa supported by the results of qualitative analysis which the husbandsaid that they supported the pregnant mothers to consume the iron tablet where the most frequent support was to remind to consumption. This support is significant to remember that iron tablet must be taken every day in the long-term (9).

Obtained answer at instrumental and reward support was still low. It supported by the answer of the mother informants, who stated that husbands were seldom to prepare drink and tablet to consumption every day and less credit as well. This kind of support is essential to remember taking the tablet at night, carry it when hope to stay at other places and to motivate if laziness and side effect occurred (11).

The result of an interview of the husband informants supported the statement of the pregnant mother where the husband said that only once help prepare and even there was a husband who firmly said never serve. He also stated seldom even never give any compliment to pregnant mother if they obey to consume the tablet. Whereas, support from the closest person will elevate the mothers' spirit to keep her healthy during pregnancy (15).

According to Wiradyani and friends, excellent support from midwife or husband has a contribution to make Compliance in taking the iron tablet. The individual who got support, believe that individual is loved, appreciated and part of her social environment. Multiple logistic regression test result with a backward method showed that there was a significant relationship from midwife to the Compliance of taking the iron tablet. Statistically seen from value OR 15.297 (95\% Cl: 2.316 - 101.027) explained that 
midwife support had 15.297 times possibilities to make mothers obey to consume the tablet. The effect felt was happiness, spirit raised, calmer, helped during pregnancy. The support given by midwife and husband may be emotional, informational, instrumental and complimentary support. Where if this support is given optimally believed able to increase the Compliance of pregnant mothers in taking the iron medicine. Supported by various people is believed to affect mothers to successfully pass all challenge during pregnancy 10).

Indeed, the iron tablet gives side effect such as Bored, nausea, vomit, bowel obstruction and black faeces. Based on chi-square statistic test with a level of trust $95 \%(\alpha=0,05 \%)$ showed that there was a significant relationship between the side effect and pregnant mothers' Compliance in taking the tablet with $p$-value 0,340 . It was supported by informants' statement that even though experiencing the side effect from the tablet but still obey to consumption because the informant knew the function and stuck to the suggested by a midwife to take medicine at night. It also supported by midwife informants, where they always recommend the mother to take the iron tablet at night before sleeping to avoid queasily and absorption the iron more optimal. It was in line with the research of Wiradnyani (10), good respond to the side effect will minimize the effect from the Fe tablet. Some studies show that side effect upon the Compliance of mother to consumption the IFA tablet is just little (9).

\section{CONCLUSION AND RECOMMENDATION}

Based on the data analysis, the research and explanation of the discussion stated that the respondents who take iron table had occurred frequently to excellent educated pregnant mothers who were $(37.0 \%)$, husband support (40.7\%), midwife support (44.4\%), experiencing mild side effect $(28.4 \%)$. Based on chi-square analysis, there was a significant relationship between knowledge $(p=0,000)$, husband support $(p=0,000)$, and midwife support $(p=0,000)$ with Compliance to take iron medicine. However, for side effect made by iron $(p=0,340)$ did not have a significant relationship with iron Compliance. It was supported by informants statements which stated that iron is good for pregnancy even though they were bored, the informants still eat the medicine regularly. They also confirmed that husbands and midwives gave informational, emotional and instrumental support. The results of this study can be used as a basis for further research. The author suggests to explore data related to customs and self-confidence.

\section{REFERENCES}

1. Assefa, Habtamu, Solomon Mekonnen Abebe, and Mekonnen Sisay. 2019. "Magnitude and Factors Associated with Adherence to Iron and Folic Acid Supplementation among Pregnant Women in Aykel Town, Northwest Ethiopia." BMC Pregnancy and Childbirth 19(1): 1-8.

2. Tarekegn, Missa et al. 2019. "Antenatal Care and Mothers' Education Improved Iron-Folic Acid Adherence at Denbiya District Health Centers, Northwest Ethiopia: Using Pills Count Method." Archives of Public Health 77(1): 1-6..

3. Yogyakarta Health Office. 2016. Health Profile of Yogyakarta City. Yogyakarta

4. Alifah, Rizqi. 2016. Factors Affecting Compliance Pregnant Women Consuming Iron Tablets In Puskesmas Gamping 2. Thesis. University Muhammadiyah of Yogyakarta.

5. Gibney, M.J. 2009. Community Health Nutrition. Jakarta: EGC.

6. Hikmawati. 2014. Relationship Knowledge and Support Husband Pregnant Woman Trimester III with Compliance to Consume Iron Tablets at Health Center Karangayu 2014. Journal of Midwifery. ISSN .2089-7669 
7. Sinaga, E.J. 2015. The Influence of Knowledge, Attitude, Support Husband, And Motivation of Health Personnel Against Compliance Pregnant Women Consuming Iron Tablet In Puskesmas Sitinjo Daiti Regency Year 2015. Thesis. USU.

8. Gebremichael, Teklu Gebrehiwot, Hansa Haftu, and Teklebrhan Aregawi Gereziher. 2019. Time to Start and Adherence to IronFolate Supplement for Pregnant Women in Antenatal Care Follow up; Northern Ethiopia. Patient Preference and Adherence Volume 13: 1057-63.

9. Taye B., Gedefaw Abeje1, Alemetsehaye Mekonen. 2014. Factors Associated With Compliance Of Prenatal Iron Folate Supplementation Among Women In Mecha District, Western Amhara: A Cross-Sectional Study. Pan African Medical Journal. 2015; 20:43 Doi:10.11604/Pamj.2015.20.43.4894

10. Wiradnyani L., Khusun H., Achadi L. 2013 Factors Associated With Mother Compliance Eating Iron-Folate Tablets During Pregnancy. Journal of Nutrition and Food, 8 (1), 63-70.

11. Fatimatasari, Fatimatasari, Hamam Hadi, and Nur Indah Rahmawati. 2016. "Kepatuhan Mengonsumsi Tablet Fe Selama Hamil Berhubungan Dengan Kejadian Bayi Berat Lahir Rendah (BBLR) Di Kabupaten Bantul." Jurnal Ners dan Kebidanan Indonesia (JNKI) 1(3): 87
12. Mbhenyane, Xikombiso, and Matodzi Cherane. 2017. "Compliance with the Consumption of Iron and Folate Supplements by Pregnant Women in Mafikeng Local Municipality, North West Province, South Africa." African Health Sciences 17(3)..

13. Kautshar N, Syria, Jafar Nurhaedar. 2013. Compliance of Pregnant Women in Consuming Iron (Fe) Tablets at the BaraBaraya Health Center in 2013. Thesis. USU 14. Dutta A.J., Patel P.B., Bansal R.K. 2014. Compliance To Iron Supplementation Among Pregnant Women: A Cross Sectional Study In Urban Slum. Natl J Community Med 2014: 5(4);457-62

15. Lubis, Desi Handayani. 2016. The Influence of Husband's Support, Knowledge and Attitudes of Pregnant Women Towards Antenatal Care Visit in the Work Area of the District Health Center in West Medan District. Thesis. USU

16. Sari, S. I. P., Noviani, A., Masdiputri, S. N., \& Inayah, N. (2017, February). Relationship Of Education, Family Income, Compliance And Procedure Consumption Of Iron Tablet To Anemia Among Pregnant Women. In Proceedings of the International Conference on Applied Science and Health (No. 1, pp. 210-215). 